\title{
Equality as an Effect of Meaning and the Uncertainties of the Legal Discourse
}

\author{
Dionéia Motta Monte-Serrat, Leda Verdiani Tfouni \\ University of Sao Paulo, Sao Paulo, Brasil
}

\begin{abstract}
The study on the concept of subject according to the theories of Discourse Analysis, Literacy, and Lacanian psychoanalysis led us to understand it like an effect of meaning. In this line of thought, the subject, when observed in the relations of power specified by the law (during a court hearing), acquires a political dimension that allows us to differentiate the concept of the juridical subject (as an effect of language) from the concept of the subject of law. We analyze linguistic and enunciative facts in the Law discourse and contrarily to the proclaimed equality under the law, we can detect places where it is inequality proper that settles in.
\end{abstract}

Keywords: uncertainty, exclusion, Law discourse, juridic discourse

\section{Introduction}

Juridicism is a characteristic of all social relationships, and it means "an appreciation of acting" (Lagazzy, 1988).

In the enunciation of a court hearing, such juridicism reaches its maximum level, that is, any enunciation that does not take place as prescribed by law loses its value and is disregarded by the legal system.

In this study, we investigated enunciation within the rite of a court hearing, but under the perspective of the theories of Discourse Analysis (Pêcheux, 1988) and Literacy (Tfouni, 1992, 2005), keeping in mind that enunciation is a place where the subject is constituted and that a subject is conceived as effects of meaning between interlocutors within a socio-historical context.

Under the perspective of such theories, we understand enunciation and the text genre investigated in this context (sentence, court records) as places that comprehend the subject's legal dimension in the discursive chain. That is to say, the subject is not fixed or predictable, but it will be observed in its flexible dimension.

\section{The Law Discourse vs. the Juridic Discourse}

Our starting point to observe the subject's legal dimension in the discursive chain is the difference existing between the concepts of the Law discourse and of the juridic discourse.

The Law discourse is the discourse of certainty, of transparency, and of a single meaning. Based on the order of "must-be", it determines a ritual of overlapping turns of speech, with the purpose to provide cohesion to

Dionéia Motta Monte-Serrat, Ph.D., Philosophy, Science and Letters Department, University of Sao Paulo. Leda Verdiani Tfouni, professor, Philosophy, Science and Letters Department, University of Sao Paulo. 
enunciation and a single meaning.

The juridic discourse, in turn, takes into account that the subject is constituted in enunciation, and it is an effect of language, both divided and opaque, and that it breaks up with the meaning unit of the Law discourse.

The subject, when observed in the power relations determined by law (during a court hearing in which the judge listens to witnesses, clips their statements, and dictates to the clerk what he understands must be included in a written document), acquires a political dimension that allows for differentiating the concept of a juridical subject (who is an effect of language) from the concept of a subject of law (the one who is to the law-Haroche, 1992, p. 158).

\section{The Event of Literacy in Court Hearing}

During a hearing, when a witness reports to the judge the facts that he/she has witnessed, a subject is being constituted. In our study, we compared the transcription of witnesses' recorded depositions to court hearing records (written records of depositions under the judge's dictation) and observed lapses that disagreed with the subject image proposed by law.

In face of such lapses, we questioned the ideological effects inherent to the Law discourse, which imposes certainty, single and transparent meanings and imposes the "appropriate way" of writing in order to supposedly prevent ambiguities and uncertainties.

In this rite, we observed tension in establishing meanings and the marginalization of subjects with a low literacy level (Tfouni, 2005). While the Law discourse proclaims a measurable and predictable subject, an opaque meaning and failure-susceptible subject emerge from the witnesses' narratives. Hence, contrarily to the proclaimed equality under the law, we can detect places where it is inequality proper that settles in.

We observed that in the rite of a court hearing - when the judge listens to a party or witness, he cuts off parts of the depositions as he considers to be necessary and dictates what is going to be included in the court records to the clerk - the idea of transparency of the Law discourse rules, bringing the impression that the authors', defendants', or witnesses' statements correspond exactly to what is dictated to the court clerk by the judge.

The subject that is constituted in the judicial rite is the subject of law, who occupies places which are previously configured by law, overlapping the deposing subject's interpretative actions. The text genre practiced by the judge (as the one who is knowledgeable about the law) follows logical reasoning, which, for being formal, makes his intervention "natural" and excludes discourses filled with subjectivity.

In the enunciation during the judicial rite, a measurable and predictable subject is formed (Haroche, 1992): It is the ideological subject of law that is constituted as determined by law when making a correspondence between what was said and what was written. It is conceptualized as a "judicial illusion" (Edelman, 1980, p. 14) whose will is associated with an "appreciation of acting" (Lagazzy, 1988). To Haroche (1992, p. 158), the must-be of the law constitutes the subject of law in order to bear the overlapping of the judge's statements over the witnesses', so that cohesion of meaning can exist.

The overlapping of the subject of law's image over the witnesses' interpretative actions occurs in an "invisible" fashion, in an ideological effect over the subject, according to the materialist theory of discursive processes (Pêcheux, 1988, p. 152). Hence, the subject is constituted from his/her forgetting what determines $\mathrm{him} / \mathrm{her}$. He/she does not realize that he/she deposes from an ideological position (social enunciation place) that 
determines what can and what cannot be said. This is the subject's fully visible form of autonomy (Pêcheux, 1988).

It so happens that the historical constitution of meaning in the realm of court hearings causes it not to be unique, as determined by the Law discourse.

The context of the Judicial Branch, under the view of the legal discourse, allows for perceiving the existence of the paradox of the "belonging of non-included individuals" or of the "equality of the unequally divided" (Guimarães, 2002, p. 18), who occupied places according to the criteria of "their rights to saying" and for their "ways of doing".

\section{Equality Under the Law Under the Paradox of Devaluation of Subjectivity}

The theories of Literacy (Tfouni, 1992, 2005) and Discourse Analysis (Pêcheux, 1988) explain how this paradox that naturalizes the devaluation of subjectivity-filled discourses by subjects with poor literacy occurs. To these theories, meaning is subject to lapses and failures.

The appreciation of statements in court hearings stems from the functioning of the grammar in the Law discourse, which is not neutral, but crucial for the construction of meaning of what is enunciated: It constructs a consensus and brings the illusion of a "semantically balanced world" (Pêcheux, 2002). The judicial rite produces the subject and meaning.

The acts of enunciation during a court hearing are related to something that is beyond them (law), which dictates the meaning of statements towards a certain direction. The Law discourse brings fetishism by attributing the extraordinary virtue of "correspondence" between what a witness said and what was written by the court clerk under the judge's dictation. The witness-subject finds himself/herself in an illusion of autonomy when he/she responds to the judge (see Example 1).

Example (1)

(91) J ((questioning the witness)): And there, at that other address on (X) Street... what

(92) is it there?

(93) T1: There is a shed... it's closed, but there are some gaps, and you can see that all the

(94) equipment is in there... there's some light pole stuff ... I think that they

(95) work in this business of::: these standard light ... poles

(96) J ((dictating)): Yes::: saw that the property on (X) Street is a shed ... in

(97) which light poles are produced

(98) J1 ((questioning the witness)): Residential... is that it?

(99) T1: Yes... these light poles... there's a lot of light pole equipment in there I don't know if they are (---)

(100) J ((questioning the witness)): for homes, for houses?

(101) T1: Yes

(102) J ((dictating)): for homes

(103) T1: And the equipment that they took, that fitted, it is also all there

(104) J: Do you know if they... Ms. (Y) ... if she::.: is being charged for other debts?

(105) T1: Of course that::: the others go there to collect debts from::: from::: for the gutter that they

(106) had installed in the place and didn't pay for

(107) J ((dictating)): [...] 
In view of the witness's disperses statements, the judge directs their meanings by producing the enunciations according to the law.

We place the subject of law in the ideological subject-position. Regarding the judge, as a legal expert who bases on the rigor of legal texts whose rite keeps him away from discursive materiality, he has nothing to say that is his own (Legendre, 1976, as cited in Haroche, 1992, p. 190). It is a subject-position that seeks to void subjectivity for the sake of a logically balanced universe (Tfouni \& Pereira, 2009).

\section{The Continuum of Literacy and the Subject-Positions}

The written practices developed during a court hearing of the Judicial Branch can be applied to the continuum of literacy developed by Tfouni (1992, p. 26), so that we can place: (1) the subject of law out of the discursive chain, on an ideological plane; (2) the law subject (position occupied by the judge, as a legal expert), on the end of the most literate participants, whose thinking is more sophisticated (logical reasoning); and (3) the juridical subject (all the other subject-positions) along the discursive chain (see Figure 1).

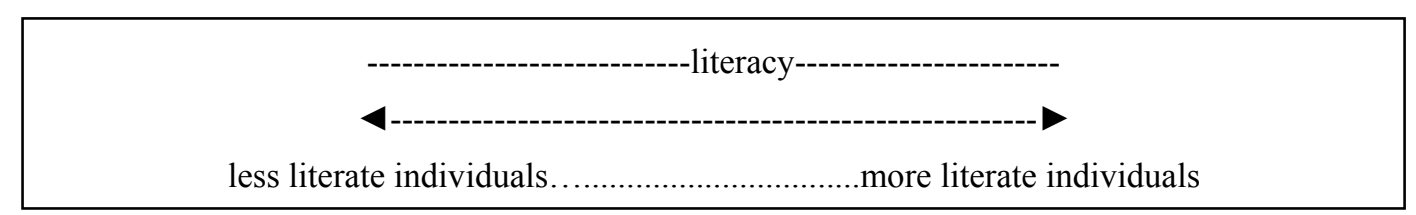

Figure 1. Continuum of literacy. Source: Adapted from Tfouni (1992).

\section{Unmaking the Ideological Effect of Certainty Between What Was Said and What Was Written}

The transcription of the witness's statement corresponds to the following part of the court hearing records as dictated by the judge (see Example 2):

Example (2)

[...] The witness saw that the property on... Street is a shed in which residential light poles are produced. Several people have been to the place (property on... street) to collect debts from the defendant [...]

The rewriting for which the judge is responsible brings certainty to the dispersed statements of witness T1, thus eliminating meaning shift, suppressing the deposing-subject's subjectivity and, finally, erasing the subjectivity-filled of the juridical subject (Tfouni, personal communication, May 12, 2010)

The juridical subject, the subject of enunciation, corresponds to the functioning of the "subject-form" (Pêcheux, 1988, pp. 163, 183) along the discursive chain. He/she does not acknowledge his/her subjection to the state because he/she is constituted under the effects of meaning that circulate in the context where the law dictates what must and what must not be done. In the juridical subject, there is polysemy, meaning shift, and opacity. $\mathrm{He} /$ she diverges from the subject of law.

\section{Conclusions}

The discursive perspective of court hearing enunciations allows for perceiving aspects that reach beyond the content and form of court hearing records. We could see in Examples 1-2 that the certainty of Law discourse 
means devaluation of subjectivity. The importance of this study is to show that the incompatibility between the subject of law and the juridical subject can be surpassed, since in discursive materiality, they co-exist under the appearance of the paradox that affirms "the belonging of the non-included" (Guimarães, 2002, p. 18).

When we investigated enunciation within the rite of a court hearing under the perspective of the theories of Discourse Analysis (Pêcheux, 1988) and Literacy (Tfouni, 1992, 2005) keeping in mind, that enunciation is a place where the subject is constituted and that a subject is conceived as effects of meaning between interlocutors within a socio-historical context. The ritual in the discursive practices of the Law discourse allows us to consider as different the concepts of law's subject and juridical subject. While the first is related to cohesion and to a single meaning, the second is linked to what Pêcheux (1988) calls "speaking intersubjectivity" and appears as an effect of language, both divided and opaque. We can observe the disruption of the law's subject cohesive image within the ritual of the judicial court session — characterized by a superposition of speeches—when the grammar of Law discourse works outside its logical process, out of a kind of fetishism that surrounds the mode of operation of ideology and the unconscious. When we move away from this practice, we found that, under the image of the law's subject, inside the discursive functioning, there is the image of the juridical subject, steeped in subjectivity and marginalized by the discourse of law. Although interpellation by ideology masks the material character of meaning by imposing transparency to it, Pêcheux brings a warning about the possibility of resistance and revolt within the process of subjection. This event leads us to the conclusion that subjectivity is a place that plays a dual role: that of disclosing subjection and that of disclosing its subversion, thus breaking the vicious circle of idealism and interrupting the tragic fate of the subject that is captured by ideological interpellation.

Along the discursive chain, within the proposal of the literacy continuum (Tfouni, 1992, 2005), we can consider social inequalities, heterogeneous discursive practices and subjectivity as different nuances of the subjects' political conceptualizations, since we considered the subject of law (unique and measurable) in his/her ideological aspect; and, on the other hand, the law subject ( the subject-position occupied by the judge) and the juridical subject as dimensions of the subject's constitution in discursive materiality.

On the ritual of overlapping speeches of the event of an audience of the Judiciary, under the application of the theory of Discourse Analysis, we observe that the cohesive image of the body described by the discourse of the Law is broken with the emergence of a split subject, constituted on a discourse of another order, outside the legal logic. If the discourse of the Law describes the body, we may assert that the displacement of the rigid structure of the syllogism characterizes a resistance to the dominant ideological formation of this discourse, as something that brings up what was repressed, making the law a trace without a body (Christin, 2001, p. 15).

\section{References}

Althusser, L. (1999). Ideology and ideological state apparatuses (Ideologia e Aparelhos Ideológicos do Estado). In S. Zizek (Org.), Mapping ideology (Um mapa da ideologia) (pp. 105-142). Rio de Janeiro: Contraponto.

Bahktin, M. (1981). Marxism and the philosophy of language (Marxismo e filosofia da linguagem). São Paulo: Hucitec.

Bourdieu, P. (1998). Language and symbolic power (O poder simbólico). Rio de Janeiro: Berthand Brasil.

Christin, A.-M. (2001). The written image or the graphic unreason (L'image écrite ou la déraison graphique). Paris: Flamarion.

Edelman, B. (1980). The sociology of law: An introduction (La Practica Ideologica del Derecho). Madrid: Editorial Tecnos.

Guimarães, E. (2002). A study in semantics deals with the relation of designation (Semântica do acontecimento: Um estudo enunciativo da designação). Campinas, SP: Pontes.

Haroche, C. (1992). What people are saying (Fazer dizer, querer dizer). São Paulo: Hucitec. 
Lagazzy, S. (1988). The challenge to say no (O desafio de dizer não). Campinas: Pontes.

Legendre, P. (1976). Treaty of patriot bureaucracy (Jouir du povoir (Traité de bureaucratie patriote)). Paris: Éditions Minuit.

Luria, A. (1977). Cognitive development-Its cultural and social foundations. Cambridge: Harvard University Press.

Mainguenau, D. (1997). Discourse analysis in France: A conversation (Novas tendências em análise do discurso). Campinas: Pontes.

Miaille, M. (1979). Critical legal studies (Uma Introdução Crítica ao Direito). Lisboa: Moraes Editores.

Negrão, T., \& Gouvêa, J. R. F. (Eds.). (2007). Brazil Law No. 5869 of January 11, 1973, Code of Civil Procedure (Brasil, Código de Processo Civil, Lei 5869, de 11.01.1973). São Paulo: Saraiva.

Pêcheux, M. (1988). Language semantics and ideology: Stating the obvious (Semântica e discurso: Uma crítica à afirmação do óbvio). Campinas: Ed. Unicamp.

Pêcheux, M. (2002). Discourse: Structure or event? (O discurso: Estrutura ou acontecimento?). Campinas: Pontes.

Silva, D. P. (1987). Law dictionary (Vocabulário jurídico). Rio de Janeiro: Editora Forense.

Souza, S. (1995). Bakhtin: Ideological and dialogical dimension of language (Bahktin: A dimensão ideológica e dialógica da linguagem). Infância e linguagem: Bahktin, Vygotsky e Benjamin. Campinas: Papirus.

Tfouni, L. V. (1992). Literacy and iliteracy (Letramento e analfabetismo) (Full professor thesis, University of São Paulo).

Tfouni, L. V. (2005). Literacy (Letramento e alfabetização). São Paulo: Ed. Cortez.

Tfouni, L. V., \& Pereira, A. (2009). Literacy and the resistance to the scriptural economy (Letramento e formas de resistência à economia escriturística). Revista Forum Linguístico, UFSC, 2. 